\title{
Experimenting the Modern Story “Mr. Tepis” to Balinese Topeng Masked Dance Theatre
}

I Wayan Dibia, Taipei National University of the Arts,

Taipei, Taiwan

w_dibia@yahoo.com

(C) 2016 University of Malaya. All rights reserved.

Malaysian Journal of Performing and Visual Arts, Volume 2, 2016

\begin{abstract}
Topeng, one of Bali's most important theatrical forms, has always been identified as a masked dance theatre enacting Balinese chronicles (babad). Some have perceived the babad story as the most essential element and the cultural identity of topeng more than the use of masks. Using the production of Topeng "Mr. Tepis" as a focus of discussion, this paper presents an artistic endeavor to experiment a modern story to Balinese topeng masked dance theatre. The primary goal of this paper is to show that introducing modern stories into traditional theatre such as topeng may change the old image of the art form without destroying its aesthetic principle and cultural identity. ${ }^{\boldsymbol{I}}$ The use of modern story may help topeng to maintain its popularity amidst the ever changing culture of Bali.
\end{abstract}

Keywords: Wayang topeng, Topeng "Mr. Tepis", Balinese theatre, masked dance, experimental theatre

\section{Introduction}

The island of Bali is home to various theatrical forms using masks. Presently, there are five major art forms featuring masks still actively performed on the island. This includes wayang wong (Ramayana masked dance drama), topeng masked dance theatre, barong dance drama, legong topeng dance, telek and jauk dance. Enacting stories derived from different resources, each form utilizes wooden masks representing different figures and characters, ranging from gods and spirits, to human beings, animals, and demons. Among these forms, up until now, perhaps topeng is the most popular masked dramatic form on the island.

Most stories for topeng are derived from the Balinese chronicles known as babad, a semi-historical works. Traditionally written on palm leaf manuscripts or lontar, the babad depicts the journey of local kings and noblemen as well as Balinese ancestors. Since most of its stories are derived from babad, topeng has always been identified as babad masked dance theatre. Many in Bali also believe that the babad story is the most essential element of topeng more than the use of the mask. This creates an image of 
topeng identical to the dramatization of babad stories. Unfortunately, this is not the best perception of topeng, for it in fact ignores the flexibility of this traditional dramatic form, including the use of dramatic resources.

As a Balinese topeng dancer, I find topeng a very flexible dramatic form. This dramatic form is open to different kinds of story, and its performance provides room for both the old and contemporary cultural expression to collide and interact. In order prove this, in December 2011, I produced a new masked dance theatre entitled Topeng "Mr. Tepis" at Geria Olah Kreativitas Seni (GEOKS), a performance space located in Singapadu-Gianyar (see Figure 1).

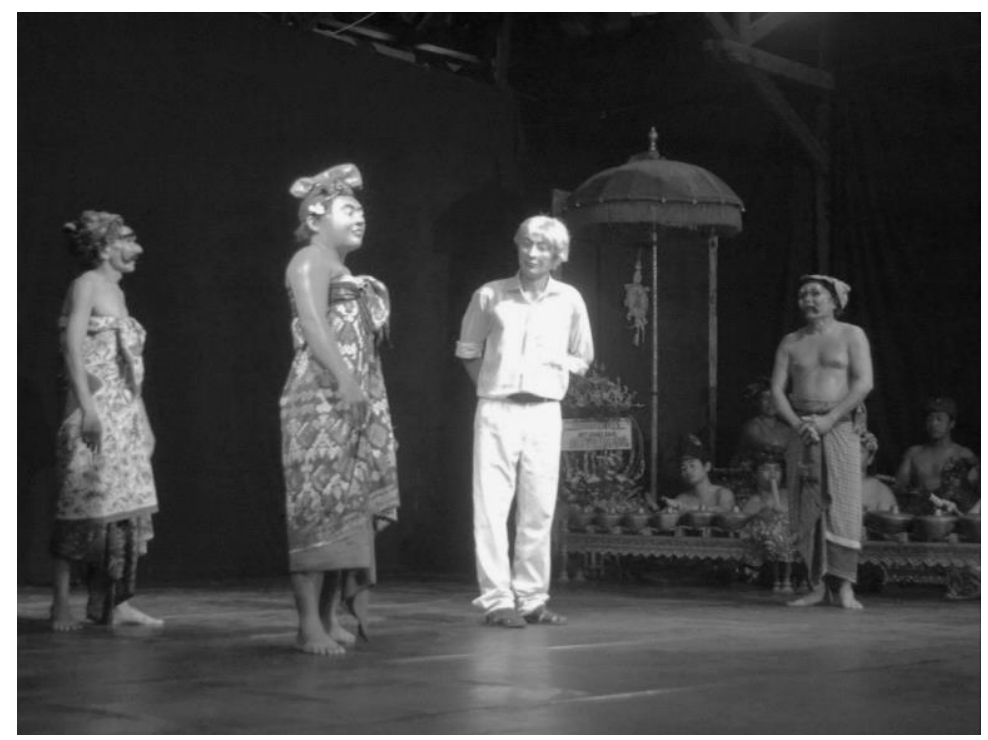

Figure 1. An audience scene between Walter Spies (in white) and Cokorda Gde Agung Sukawati, prince of Ubud (in purple) in Topeng "Mr. Tepis" at GEOKS-Singapadu 2011.

This artistic experimentation was carried out by utilizing a modern story; the life of a German artist and scholar, Walter Spies, who lived in Bali since 1927, to traditional Balinese topeng. However, the use of this modern story requires some significant aesthetic changes and theatrical innovations, including creating new masks and deconstructing the formal performance structure of the traditional Balinese topeng. Despite this, the essential element of topeng, playing with masks, especially of "human" masks, remains dominant in the new topeng performance.

The creation of this new topeng was intended to change the image of topeng as a masked dance theater reperesenting the feudalistic cultural values of the past. It is my hope that the creation of Topeng "Mr. Tepis" will help Balinese audiences broaden their perception about topeng, and to stimulate other artists on the island to experiment with other new stories into this masked dance theatre. This is perhaps a way to help the topeng to maintain its popularity amidst the globalized Bali. 


\section{Topeng in Balinese Tradition}

Masked performance is one of the most important elements of Balinese cultural tradition. In order to understand the position of the new Topeng "Mr. Tepis" in Balinese performing arts, it is important for one to know the existing topeng variants on the island.

Despite the change of socio-cultural values in Balinese tradition, topeng masked dance theatre continues to have a special place in the religious, social, and cultural activities of the Hindu Bali people. Up until now, topeng is highly respected by Balinese community members. In spite of the increasing influence of modern sophisticated entertainment on Bali, topeng performances, both in rural and urban communities, continue to attract many people.

The word in Balinese language for mask is tapel (from tup which means to cover) literally meaning "to close or press against the face" or "to conceal or transform the identity" of the person who wears it. In this case, masks are used to conceal and depersonalize the wearer (Emigh, 1998, p. 8). By using a mask one can conceal and transform his own identity, and ultimately to become a new character.

Masked performances are an old tradition in Bali. Some archival evidence indicates that masked performances were already developed as early as the ninth century. One of the earliest records of masked performances is the Bebetin manuscript, dating back to the Caka year 818 or 896 A.D. (collected by the Gedong Kirtya Library in Singaraja-Bali) (Simpen, 1974, p. 3). Among the important terms found in the manuscript, which suggest performances using masks, are partapukan, atapukan, or hanapuk (tapuk means "to cover" or mask"). ${ }^{3}$ These words signify masked performances, in which to create a character an actor-dancer puts something to cover the face. However, no one knows whether the mask performances mentioned in the manuscript are the same as the masked dance theatre one presently encounters in Bali.

About the origin of topeng, I Made Bandem and I Nyoman Rembang (1976) wrote that the present form of topeng developed between the fifteenth to sixteenth century. They mentioned that in the palm-leaf manuscript Ularan Prasraya [The Minister Ularan on his Mission to Blambangan in East Java], King Waturenggong, who reigned in Gelgel between 1460 and 1550, wanted to invade Blambangan (East Java). He sent forces under the leadership of Minister Ularan accompanied by I Gusti Jelantik Pesimpangan. After killing King Juru of Blambangan during a deadly fight, Minister Ularan brought a box of Eastern Javanese masks to Bali and presented them to King Waturenggong. According to this manuscript, these masks, the loots of the Blambangan war, were treasured as sacred objects at the Penataran Topeng temple of Blahbatuh in Gianyar district (Bandem and Rembang, 1976, p. 5). It is strongly believed that these masks were used by the local artists to create the topeng masked dance theatre, which then began to flourish in Bali. 
Over the last three decades, Balinese topeng has developed into four variants: topeng pajegan, topeng panca, topeng prembon, and topeng bondres (Dibia, 2013, Kodi, 2006). In brief, topeng pajegan, also known as topeng sidhakarya, is a masked dance theatre performed by a solo actor-dancer. ${ }^{4}$ This topeng variant is primarily performed for ritual, as a sacred and religious art (wali), or as ceremonial art form (bebali). As a ritual art, topeng pajegan is intended mainly to please the invisible audience, the gods and deities who temporarily reside inside the temple, including deified ancestors. Topeng panca literarily means topeng dance theatre acted by a group of five actors or more. Some speculate that this topeng variant first appeared around the eighteenth century, if not later. Topeng panca began to reach its popularity around the 1930s, and it is still a popular theatrical form in Bali today. ${ }^{5}$ Topeng prembon is essentially a mixed dance theatre featuring characters with and without masks. A derivative of the topeng panca, combining elements of topeng and the opera dance-drama of Bali called arja, this dance theatre emerged in 1942 through a collaborative production of a group of artists from Gianyar and Badung regencies. The creation of this dramatic form was strongly stimulated by the growing awareness of the local artist about their new provincial and national roles during the revolution of Indonesia at this time. With the inclusion of arja roles, topeng prembon becomes a theatre of male and female artists, though male actors still dominate the performance. ${ }^{6}$ Topeng bondres is a masked dance theatre dominated by comic characters, such as clown servants and villagers, and its performances contain endless spontaneous humor. Created around the early 1980s, topeng bondres is a masked dramatic form without formal performance structure. It tells no literary story and its entire performance is filled with humor. The play may begin with a dramatic scene from a classical story, but then it digresses into spontaneous critiques and comments on current issues.

The emergence of these topeng variants in Bali indicates the never-ending creativity of topeng performers on the island in their attempt to satisfy the changing artistic taste of the local artists and audiences. It is important to note that the use of masks portraying human figures remains dominant in all topeng performances. This strongly suggests that the human mask, of different characters and social status, is one of the most essential elements, and therefore the key aspect to the cultural identity of topeng masked dance theatre of Bali.

Since the late 1990s, topeng has been discussed in many scholarly works. Among the most relevant works to examine are a Master thesis by I Nyoman Catra (1996), two books by Judy Slattum and Poul Schraub (2003) and Margaret Coldiron (2004), articles by Kathy Foley (2005) and I Wayan Dibia (2013).

An examination of Balinese cultural reflection on topeng masked dance drama is presented by I Nyoman Catrain in a thesis entitled "Topeng Mask Dance-Drama as a Reflection of Balinese Culture: A Case-Study of Topeng Prembon" at Emerson College, Boston. In the conclusion of his thesis, Catrain mentions the flexibility of Balinese topeng. He writes: "Mask dance as an art has many opportunities to develop. It is very flexible and has numerous possibilities in creative works" (1996, p. 158). This shows that topeng is a traditional theatrical form that is open to creativity. 
A comprehensive observation on the use of mask in Balinese performing arts is presented by Judy Slattum and Poul Scruaub in their work entitled Balinese Masks: Spirits of an Ancient Drama (2003). In this book, with various beautiful pictures of old Balinese masks, the authors mention the importance of masks in Balinese cultural tradition, especially in their performing arts. Four Balinese masked dance theatre generally discussed in these works are topeng, wayang wong, calonarang, and barong. In their discussion on topeng, the authors only examine two topeng variants: topeng pajegan and topeng panca.

In 2004, Margaret Coldiron presented a brilliant study on two profound aspects of Balinese topeng in her book entitled Trance and Transformation of The Actors in Japanese Noh and Balinese Masked Dance Drama. When comparing the state of mind of Balinese topeng actor-dancers with those of the Japanese Noh, she claims that mask is one among several elements of performance which contribute to the masked performer's altered state of consciousness (2004, p. 310). Like Slattum and Scruaub, Coldiron also used topeng pajegan and topeng panca as the focus of her discussion.

In 2005, Kathy Foley and I Nyoman Sedana presented two long articles on Balinese topeng performances in Asian Theatre Journal entitled "Topeng Sidha Karya: A Balinese Mask Dance" and "Balinese Mask Dance from the Perspective of a Master Artist: I Ketut Kodi on Topeng". Based on topeng Sidha Karya performance, in their first article the authors explains the connection between topeng performance and the chanting of the Hindu priest (pedanda) in Balinese religius ceremonies. Using the concepts of sekala, the seen world, and the niskala, the unseen world, the authors claim that the topeng actor is in charge of the sekala and the pedanda is in charge of the niskala (2005, p. 176). Based on their interview with Ketut Kodi, in their second article, the authors mention the balance between the entertainment and religious function of topeng in Bali (2005, p. 201). In this way,the authors remind topeng lovers on the island of the function of topeng performance that they claim to be "the balance between teaching and entertaining" (2005, p. 200).

In Performing Arts in Postmodern Bali (2013) edited by Kendra Stepputat, I wrote an article entitled "Topeng Masked Dance Theatre in Globalized Bali". In this article, I discuss the existence of the four variants (topeng pajegan, topeng panca, topeng prembon, and topeng bondres) of Balinese topeng. The main purpose of this article is to show that despite the rapid change of Balinese culture, topeng continues to play important parts in many aspects of Balinese rituals.

Based on the six works on Balinese topeng described above, one can see that topeng "Mr. Tepis" has never been investigated. This creates an impression that Balinese topeng has never been innovative. The emergence of topeng "Mr. Tepis" proves that Balinese artists, especially topeng performers, are never tired of introducing new ideas into their performance, mainly to maintain the popularity of their respected art form. 


\section{The Elements of Topeng Performance}

Topeng is a complex masked dance theatre integrating various artistic elements. Among the most important elements are mask, dance and acting, story, costume, and gamelan music. In order to portray a character on stage from a story, each actor-dancer wears a mask with a typical costume, and utilizes dance, acting and singing.

The masks used in topeng are portrayals of human beings. They represent different types of human characters (strong and refined), age (young and old), and social status (villagers, servants, noblemen). The masks are handmade from wood, painted with Balinese pigments and accentuated with hair and jewelry. Topeng has always performed mainly by males, thus nearly all topeng masks represent male characters.

Based on their physical forms, the masks for topeng can be classified into three groups: full mask (tapel bungkulan) which covers the entire face; half mask (tapel sibakan) which covers the face from the forehead down to the upper lip; and mini mask (tapel kepehan) covering only the forehead and nose, chin and the upper part of the jaw. The full masks are for topeng keras (strong characters such as a prime minister), topeng tua (an old man) and topeng dalem (a refined king). The half masks, with or without painted eyes are used by the buffoon (panasar) and some of the clowns (bondres). Mini masks are used only by a certain type of clown. Once wearing the masks, every topeng dancer will do their best to bring the mask to life by utilizing the right movements, voice, actions, and energy. Bringing the masks alive is in fact the key to the success of a topeng performance.

A topeng performer holds his mask on his face by a rubber strap around his head. Once he has the mask in the right position and it is already in an upright position and its opening eyes will fit his sight, he then puts on his headdress. He finally sticks a decoration of flowers and specific green leaves on both sides of his chin to cover the gap between the mask and his face.

The dance movements utilized in topeng are based on gambuh, a form of courtly dance drama enacting stories based on the Panji Romance with unmasked characters (Bandem and deBoer, 1981, p. 60-61). In general, topeng choreography consists of four main movement categories: agem, tandang, tangkep, and tangkis. Agem are nonlocomotive actions while tandang are locomotive movements. Together, these two aspects make up the main part of a topeng choreography. Tangkis are transitional actions or phrases, which connect agem and tandang movement, and tangkep are facial expressions which are needed to bring the masks alive. Since there are many speaking sections in topeng performances, in-place movements and hand gestures dominate topeng choreography. On stage, the actors move creatively, either leading or following the gamelan music, to suit the expressions of the masks, which at first appear static and neutral yet once animated, take on a multitude of emotions. The gamelan music is always responsive to the dancer's movements and actions; in fact, some of their movements are used to cue the changing tempo and dynamic of the gamelan music. This signaling system between dancer and musicians, through the drummers, allows 
the actors to either shorten or lengthen their dance sequences depending upon their artistic impulse at the moment of performance and the response of the audience.

In topeng, as in most Balinese theatre, dance is a means of defining the social status, gender, and persona of the characters for the audience. The principals (usually with a full mask), representing the aristocracy, dance formally, utilizing more stylized and structured movements. To maintain their sense of formality, they reinforce their spoken lines with dance. In contrast, the servants and clowns (with half and mini masks), who represent people of the lower class, utilize rather informal, spontaneous movements, and their dances are relatively simple. In most cases, the strong or keras characters incorporate more percussive and forceful movement, and those of the refined or manis characters utilize softer, more flowing movements.

As mentioned earlier, the babad is the most dominant dramatic resource for topeng. The babad stories may depict, for example: the journeys of the Javanese priests and noblemen to Bali from Java between the ninth and the seventeenth century; the historical journeys of Balinese ancestors that took place later; the founding of many Hindu-Bali temples around the island; the inauguration of the local villages; the marriage of the local kings and their royal family members; and the role or emergence of clans in Bali. Among the most important literature containing topeng stories are: Babad Dalem or the Chronicle of the Kings which tells of the glorified history of the ancestral heritage of the high caste on the island; and Kidung Pamancangah which describes the family line of Balinese kings: Babad Blahbatuh, Babad Wug Gianyar, and Babad Mengwi are a few such examples.

The two fundamental characteristics of Balinese topeng are the use of stock characters (clown servants, king, and villagers) and improvisation. Although in some parts of topeng performance the actors may use a rather fixed choreography, with a set of movement vocabularies, in most parts of the play the dance movements are improvised in a sense that the topeng dancers spontaneously recompose the choreography on stage in the course of the performance. Based on a plot outline of the story, the performer improvises his dialogue and actions. This mode of performance reminds us of the Italian commedia dell'arte in which the actors work from a plot outline (Brockett, 1987, p. 181). Whatever the story is about, there will always be scenes to depict the life of the Balinese of the present and the past. Impressed by the fluidity of topeng performance, John Emigh claims that the play between the past and the present, the distant and the immediate, the grand and the mundane, is the heart of topeng (Emigh, 1979, p. 22).

The musical accompaniment for topeng in most cases is gamelan gong kebyar, ${ }^{7}$ one of the largest gamelan ensembles on the island, with 25 to 30 musicians, and the most popular ensemble throughout Bali. This five tone pelog scale gamelan is composed of eight different kinds of instruments, most of which are percussion. Among the important instruments in the ensemble are the vertical gongs (gong ageng and kempul), flat gong (bebende), knobbed gongs (reyong, terompong, kajar and kempli) gangsa metallophones (jegogan, jublag, ugal, penyacah, pemade and kantil), drums (kendang), 
cymbals (cengceng), bamboo flutes (suling), and the rebab. Using these instruments, the ensemble produces a 'bursting' sound (the meaning of the word kebyar) to become rich, dynamic, and complex music.

The costumes for topeng are based on the male characters of the classical gambuh dance drama. Known as the sesaputan, the basic costume is composed of several pieces of cloth worn in layers. Among the most important items of the topeng costumes are: an ornamented split robe (saput) covering the body (from chest to knee), a pair of white trousers (jaler) and a white waist cloth (kamen), a belt, a dark jacket, a pair of leggings, a decorative back panel, decorative collar, a pair of long aprons, and a pair of epaulettes. Each dancer wears a dagger or kris, a weapon and a symbol of power, across his back. The headdress used in topeng encompasses the crown-like headdress or gelungan used by the principals, a wig or sobrat, and head cloth or udeng for servants and clowns. Some clowns may also use hats, caps, or even army hats. ${ }^{8}$

Offerings are also an important element of a topeng performance. The performers of this masked dance theatre believe that their masks possess the soul and spirit of the respective characters. They always treat the masks with the utmost respect by always keeping them in an appropriate (high up) or special place, and make regular offerings to them, at home and at the performance site, before and after the performance.

Among all performance elements described above, the mask is the most essential one, without which there will be no topeng dance theatre. In line with this, bringing the mask alive on stage, by giving the right energy and movement, and the suitable voice, is the aesthetic principle to topeng. Actor dancers in Bali believe that ngigelang topeng, meaning 'bringing the mask alive', is the aesthetic principle of topeng.

\section{The Creation of Topeng "Mr. Tepis"}

Topeng "Mr. Tepis" is essentially a contemporary artistic experimentation on traditional Balinese topeng. This artistic endeavor was carried out mainly by utilizing a modern story, the life of Walter Spies in Bali in the early 1930s, into the traditional Balinese topeng.

Walter Spies, known to the people around Ubud and Gianyar as Tuan Tepis or "Mr. Tepis" was a German artist and scholar who settled permanently in Bali in 1927 (Stowel, 2010, p. 73). Spies came to Bali under the invitation of Cokorda Gde Raka Sukawati of the Ubud Palace. Upon his arrival in Bali he became a close friend of Cokorda Gde Agung Sukawati, the step-brother of Cokorda Gde Raka Sukawati, both of whom were members of the Ubud royal family. He worked closely with many visual and performing artists in Ubud-Bali. In this performance, the depiction of Walter Spies' arrival in Bali has triggered some tension among artists in Bali who were still traumatized from the Dutch and Japanese occupation. Some question the purpose of this white man coming to their island, some even suspected he was undercover agent. Feeling such a growing tension among the local people, Cokorda Gde Agung Sukawati quickly visited his community around Ubud to properly introduce Walter Spies and 
explained the reason of his coming to Bali. Upon hearing Cokorda's explaination, the local people began to receive and welcome Walter Spies warmly. ${ }^{9}$

I created this new topeng masked dance theatre in collaboration with a number of prominent artists in Bali. I Dewa Putu Beratha of Sanggar Cudamani of Pengosekan composed the musical accompaniment using the seven tone gamelan semarandhana. The masks for the lead characters (I Wayan Limbak, Cokorda Gde Agung Sukawati, and Walter Spies) (Figure 2) were made by three prominent mask makers: Ida Bagus Alit (Lod-Tunduh). Some masks for other characters were the works of Ida Bagus Anom (Mas) and I Ketut Kodi (Singapadu). The costumes were designed by the talented Balinese fashion designer, Cokorda Gde Abinanda Sukawati, from Ubud. ${ }^{10}$

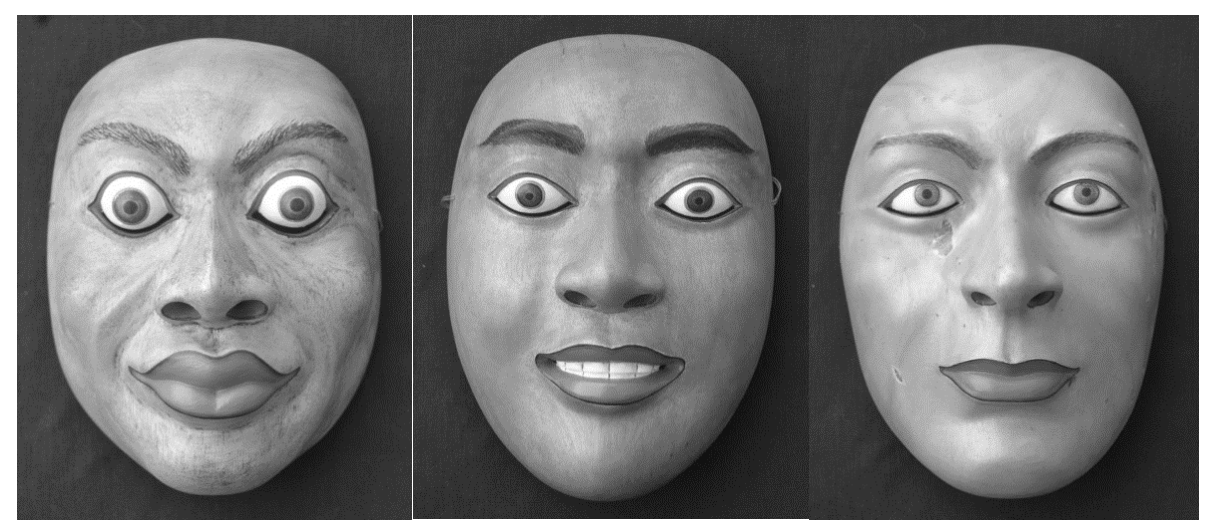

Figure 2. The masks of three lead characters in Topeng "Mr. Tepis" I Wayan Limbak (left), Cokorda Gde Agung Sukawati (center), and Walter Spies (right).

\section{Aesthetic Analysis}

Topeng "Mr. Tepis" is basically a deconstruction of the traditional Balinese masked dance theatre. The modern topeng is created by changing or even eliminating some parts and aspects of the traditional topeng, such as the use of story, performance structure, dramatic roles, masks styles, music accompaniment, and dance costumes. Despite the deconstruction of these aspects, the modern topeng still firmly holds the aesthetic principle of Balinese topeng, that is it is a masked dance theatre, in which playing mask (ngigelang topeng) remains the salient element of the performance. This is to say that in creating a new work, like modern Topeng "Mr. Tepis," Balinese artists continue to carry their artistic endeavor without losing respect to their traditional art forms.

The story used in the modern topeng masked dance, the true life of Walter Spies in Bali, is not a part of Balinese babad. The use of the modern story therefore indicates a change of dramatic resources in Balinese topeng. Unlike most babad stories which are heroic and didactic (Dibia, 2013, p. 116), with family disputes and battle scenes, the story of "Mr. Tepis" is mainly didactic. The life story of Walter Spies in Bali, with many surprising twists and turns (Stowel, 2010, p. 1), is a didactic non-violent tale. It 
is didactic because the story tells the Balinese, especially the younger generation, of the growing process of the touristic arts and tourist industry on the island that started in Ubud under the influence of Walter Spies. Also, important to note is that the modern story continues to convey Balinese philosophical concept such as duality (rwa bhineda) in life involving two opposite forces: good/positive (dharma) and evil/negative (adharma). In this story, Walter Spies and Cokorda Gde Agung Sukawati represent the good side, the villagers of Ubud, who at one point show their negative reaction on arrival of Walter Spies in Bali, symbolize the bad side. The use of a modern story breaks the domination of babad in topeng and this at once changes the old image of Balinese topeng as a theatrical form utilizing cultural values of the past, or a theatrical form playing with the past (Emigh, 1979, p. 11) into a dramatic performance of the present time, or what Alland Jr. might call the reality in Japanese theatre $(1979$, p. 3). By bringing the new image, it is my hope to prevent topeng from becoming an old-fashioned dramatic form amidst the modernization of Bali.

The performance of the modern topeng combines the concepts of the traditional Balinese topeng panca and topeng prembon. On one side, the principal characters which are featured in the new topeng dance theatre follow those of the topeng panca. On the other side, the use of some additional characters with no mask turns the modern masked theatre into topeng prembon. This strongly indicates that the modern topeng "Mr. Tepis" still belongs to two variants of Balinese masked dance theatre. Conceptually, the new topeng stands between topeng panca and topeng prembon.

Topeng "Mr. Tepis" performance unfolds into five scenes as illustrated in Table 1 below. It begins with the appearance of Wayan Limbak, a prominent dancer and master of kecak from Bedulu village, on his way home after making a short visit to Walter Spies in his home in Campuhan, Ubud. The following scene is the appearance of Walter Spies in his home. Inspired by the natural beauty of Campuhan, he creates music and painting, before leaving for the Ubud royal house to meet Cokorda Gde Agung Sukawati. The third scenes depict the meeting between Cokorda Gde Agung Sukawati with Walter Spies. The next scene shows Spies making a visit to Peliatan village where he meets his Western colleagues and friends while viewing a rehearsal of a folk gandrung dance, and to Goa Gajah where he encounters Limbak doing kecak. The last scene depicts the debate among the villagers concerning Spies' stay in Ubud. The debate stops as Cokorda Gde Agung Sukawati arrives and explains the arrival of the German artist and scholar to Ubud-Bali. Evolving in this five-scene structure is the performance of traditional Balinese topeng masked dance theatre, which always includes two main sections: the introduction or pangelembar and the enactment of the story or lampahan. However, the modern Topeng "Mr. Tepis" leaves out the first section. By cutting out the introductory characters, the entire performance belongs to the second section (lampahan). The appearance of Wayan Limbak and Walter Spies may resemble the introductory characters, the strong man (topeng keras) and the old man (topeng tua) respectively, but these characters are already integrated in the story. Leaving out the pangelembar section, as illustrated below, the presentation of the modern topeng become a tight and concise dramatic performance. 


\begin{tabular}{|c|c|c|c|c|}
\hline \multirow{2}{*}{\multicolumn{2}{|c|}{ Performance Structure }} & \multirow{2}{*}{\multicolumn{3}{|c|}{ Topeng Variants }} \\
\hline & & & & \\
\hline Sections & Act & Topeng Panca & Topeng Prembon & $\begin{array}{l}\text { Topeng } \\
\text { "Mr. Tepis" }\end{array}$ \\
\hline \multirow{2}{*}{$\begin{array}{l}\text { One: Introduction } \\
\text { (Pangelembar) }\end{array}$} & 1 & topeng keras & topeng keras & - \\
\hline & 2 & topeng tua & topeng tua & - \\
\hline \multirow{5}{*}{$\begin{array}{l}\text { Two: } \\
\text { Enacment of the } \\
\text { story } \\
\text { (Lampahan) }\end{array}$} & 1 & panasar & panasar & topeng keras \\
\hline & 2 & dalem & dalem & topeng tua \\
\hline & 3 & dukuh & dukuh & panasar \\
\hline & 4 & bondres & bondres & prabu \\
\hline & 5 & - & - & bondres \\
\hline
\end{tabular}

Table 1. The performance structure and topeng variants of Topeng "Mr. Tepis"

The dramatic roles of Topeng "Mr. Tepis" include three social strata (low, middle, high) of Balinese society and Westerners. Wayan Limbak and the village artisan represent the low caste people, the two servants of the Ubud palace are members of the secondary cast, Cokorda Gde Agung Sukawati is a member of Ubud royal house belonging to the high caste. The Westerners are represented by Walter Spies with other Western scholars and visitors such as Beryl deZoete, Chalie Chapplin, Margaret Mead, and Gregory Bateson. Using these modern figures, Topeng "Mr. Tepis" becomes a drama, or a true story, of the modern people. Featuring the mixed roles of Balinese and Western people, the performance of this modern topeng demonstrates the growing Eastern and Western cultural contact in Bali since the early decades of the twentieth century.

Almost all masks used in Topeng "Mr. Tepis" (Figure 3) represent the faces of figures who actually lived during the time Walter Spies resided in Campuhan, Ubud. These masks were built based on photos and images of the characters collected from various literatures and oral stories. The masks are not painted as traditional topeng masks using Balinese pigments, but they are simple unpainted masks with some accentuation on the eyes and lips, with eye-brows and moustache. The use of the modern representative masks indicates the influence of realism in Balinese topeng. 

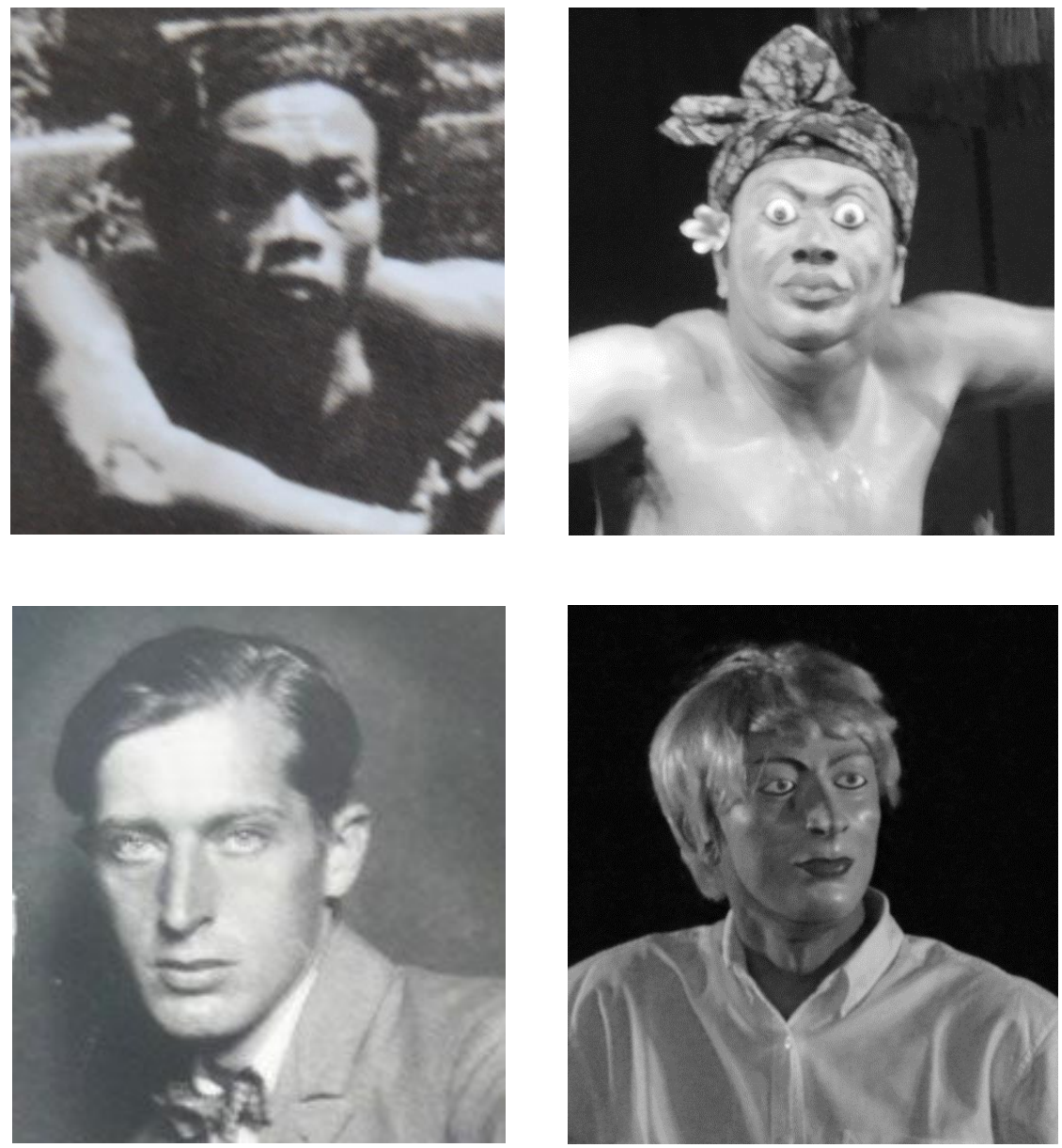

Figure 3. Above: a picture of I Wayan Limbak in Kecak Bedulu (left) and his image in Topeng "Mr. Tepis (right). Below: a picture of Walter Spies (left) and his image in Topeng "Mr. Tepis" (right)

Topeng "Mr. Tepis" is accompanied by the new gamelan semarandhana. The use of this seven tone pelog gamelan ensemble, with a wide tone range, allows the musicians to play musical compositions with various modulations and enable melodic lines to develop in Balinese topeng performance. In the past, most topeng performance was accompanied by either five tone pelog gamelan such as the modern gong kebyar or the ancient gong gede, or the four tone selendro gamelan angklung. With a limited tone range, these ensembles can play gamelan music without modulation. The use of the new gamelan semarandhana indicates a profound musical innovation in Balinese topeng masked dance theatre.

The costume for Topeng "Mr. Tepis" is based on a Balinese outfit from the 1920s dominated by faded colors. Neither crown-like headdresses (gelungan) nor brightly gold painted split robes (saput) are used in this topeng performance. All Westerner 
roles wear casual modern dresses with hats and caps. Some of them appear on stage with a camera and note book. The headdress for all Balinese figures is a head cloth or udeng of different style based on their social status. The use of the natural outfit, and the elimination of movements which involve headdresses and split robes, has reduced the feudalistic nuance of topeng performance and turned the drama into a form of folk drama.

\section{Conclusion}

I have discussed the creation process, deconstruction in many aspects of the traditional Balinese masked dance theatre, and I have briefly analyzed the aesthetic principles of the new Topeng "Mr. Tepis". I have also explained the reason of experimenting a modern story, the life of Walter Spies in Bali, into Balinese topeng masked dance theatre with the aim to change the old image of topeng and with the hope to keep the popularity of this traditional dramatic.

\section{Endnotes}

${ }^{1}$ This article is a revision of a paper presented at the International Conference on Performing Arts, 12-13 December 2013, at the Indonesia Institute of the Arts, Institut Seni Indonesia (ISI) Yogyakarta.

2.Professor of dance at the Indonesia Institute of the Arts, Institut Seni Indonesia (ISI) Denpasar.

${ }^{3}$ The Balinese phrase tapuk nyuhor tapuk manggis means the cap that covers the top part of a coconut or mangosteen respectively. When the actor-dancers adorn a mask, the function of the mask is similar to these caps.

${ }^{4}$ Over recent years one can see a performance of topeng Sidhakarya religious rites done by two to three dancers. This is because nowadays it is becoming more common for Balinese dancers to share the performing opportunity for ritual as part of their religious duty. Nonetheless, some find that topeng Sidhakarya with two or three dancers lessen the sacredness of the ritual topeng.

${ }^{5}$ Lately in Bali, it is common for a topeng panca performance to involve only three or four dancers. Once in a while, the same form may be acted by seven performers.

${ }^{6}$ Many in Bali consider prembon as an important concept for creativity for it allows performers with different artistic skills to interact and share their artistic talents.

${ }^{7}$ Before the spread of gamelan gong kebyar throughout the island in the 1930s, some ancient gamelan, gong luang, gong kembang kirang, and gong gede were also used to accompany topeng performance. Nowadays, while some villages may use gamelan semar pagulingan, or even gamelan angklung, most villages use gamelan gong gebyar. 
${ }^{8}$ The most common crown-like headdresses used in topeng are called cecandian and keklopingan for ministers and guards, and lelungsiran for the king.

${ }^{9}$ I constructed the life story of Walter Spies in Ubud Bali based on written information from different books and oral stories provided by informants from Ubud who knew about Mr. Spies.

${ }^{10}$ After its creation in 2011, Topeng "Mr. Tepis" has been performed at the Annual Bali Arts Festival in 2012, in a grand Campuhan-Ubud temple ceremony in 2014. The performance at the Bali Arts Festival has been aired several times by local television in Bali, and the dances of I Wayan Limbak and Walter Spies have been separately included in different performances in Bali.

\section{Bibliography}

Alland, Jr., A. (1979). "The Construction of Reality and Unreality in Japanese Theatre." The Drama Review; Performance Theory: Southeast Asia Issue. Vol. 23, No.2/T82, pp. 3-10.

Bandem, I M. and Rembang, I. N. (1976). Perkembangan Topeng Bali Sebagai Seni Pertunjukan.Denpasar: Proyek Penggalian, Pembinaan, Pengembangan Seni Klasik/Tradisional Dan Kesenian Baru Pemda Tk. I Bali.I . and deBoer, F. D. (1981). Balinese Dance in Transition: Kaja and Kelod (second edition). New York: OxfordUniversity Press.

Kanisius. . and Murgiyanto, S. (1996). Teater Daerah Indonesia. Yogyakarta:

Brockett, O. G. (1987). The History of The Theatre. Boston: Allyn and Bacon, Inc.

Catra, I. N. (1996). "Topeng: Mask Dance-Drama As A Reflection of Balinese Culture; A Case-Study of Topeng/Prembon.” Unpublished master's thesis. Boston, Massachusetts: Emerson College.

Caturwati, E., Amsar, T. and Nunung, N. (2010). "Interdisipliner Seni Pertunjukan dan Seni Rupa Dalam Budaya Kreatif Topeng Cirebon”. Jurnal Ilmiah Seni dan Budaya Panggung (Vol.2, No.1), pp.103-119.

deZoete, B. and Spies, W. (1972). [1938]. Dance and Drama in Bali. Kuala Lumpur: Oxford University Press. 
Dibia, I. W. (2013). “Topeng Masked Dance Theatre in Globalized Bali.” Stepputat, K. Performing Arts in Postmodern Bali Aachen: Institute of Ethnomusicology, University of Music and Performing Arts Graz. . and Ballinger, R. (2004). Balinese Dance, Drama, and Music: A Guide to the Performing Arts of Bali. Singapore: Periplus.

Dibia, I W. (1999). Selayang Pandang Seni Pertunjukan Bali.Bandung: Masyarakat Seni Pertunjukan Indonesia (MSPI).

Emigh, J. (1976). "Playing with the Past: Visitation and Illusion in the Mask Theatre of Bali." The Drama Review; Performance Theory: Southeast Asia Issue (Vol. 23, No.2/T82), pp. 11- 35 . . (Principal Consultant). (1998). Man and Mask; An Exhibition from Indira Gandhi National Center for the Arts (IGNCA) Collection of Masks. New Delhi: 1998.

Foley, K. and Sedana, I. S. (2005). "Balinese Mask Dance from the Perspective of a Master Artist: I Ketut Kodi on Topeng.” Asian Theatre Journal (Vol.22, No.2/Fall 2005), pp.199-213.

Gora-Sirikan. (1957). Kidung Pamancah. Denpasar-Bali: Pustaka Balimas.

Kodi, I. K. (2006). “Topeng Bondres; Dalam Perubahan Masyarakat Bali; Suatu Kajian Budaya" [Topeng Bondres Amidst the Change of Balinese Community; A Cultural Study]. Master thesis. Udayana University, Denpasar-Bali.

Murgiyanto, S. and Munardi, A. M. (1979/1980). Topeng Malang; Pertunjukan Dramatari Tradisional Di Kabupaten Malang. Jakarta: Proyek Sasana Budaya, Direktorat Jenderal Kebudayaan.

Napier, A. D. (1986). Masks, Transformation, and Paradox. Berkeley and Los Angeles: University of California Press.

Sedana, I. N. and Kathy F. (Translator). (2005). “Topeng Sidha Karya: A Balinese Mask Dance.” Asian Theatre Journal. Vol. 22, No.2/ Fall 2005, pp.131-198.

Simpen, A.B., Wayan. (1974). "Sejarah Wayang Purwa” in Serbaneka Wayang Kulit Bali. Denpasar: Listibiya Daerah Bali.

Slattum, J. and Schraub, P. (2003). Balinese Masks; Spirits of an Ancient Drama. Singapore: Periplus.

Stowell, J. (2010). Walter Spies: A Life in Art. Newcastle NSW: Afterhours books. 